\title{
Evaluating Pearl Millet (Hybrids) Genotypes for Zinc Use Efficiency through Fertilization Strategy Screening
}

\author{
C. Jemila* and R. Shanmugasundaram \\ Department of Soil Science and Agricultural Chemistry, Tamil Nadu Agricultural University, \\ Coimbatore, Tamil Nadu, India \\ *Corresponding author
}

\author{
A B S T R A C T
}

\begin{tabular}{|l|}
\hline K e y w o r d s \\
Dry matter yield, \\
Efficient genotype \\
index, Pearl millet, \\
Screening, Zinc use \\
efficiency.
\end{tabular}

\section{Introduction}

High consumption of cereal-based foods with low levels and poor bioavailability of micro nutrients is thought to be a major factor for rehabilitating soil and human health today. Among the micronutrients, zinc $(\mathrm{Zn})$ is affecting two third of the population worldwide. Zn deficiency in crop plants reduces not only yield, but also the nutritional quality of the crop. $\mathrm{Zn}$ deficiency has been reported in various parts of the world in annual crops (Cakmak et al., 1998). In a global study initiated by FAO, it showed that about $30 \%$ of the cultivated soils of the world are $\mathrm{Zn}$ deficient. About $50 \%$ of the soils used worldwide for cereal production contain low levels of plant-available $\mathrm{Zn}$ (Graham et al., 1992). Deficiencies in these nutrients can hamper early brain development, suppress the immune system, increase both mortality and morbidity, and reduce the capacity to do physical work (Combs et al., 1996; Graham and Welch, 2012). Such deficiencies can perpetuate the cycle of poverty in developing countries (Graham and Welch, 2012).

In India, zinc is now considered the fourth most important yield-limiting nutrient after, nitrogen, phosphorus and potassium. The 
critical limit of effective $\mathrm{Zn}$ in the soil suitable for crop growth is $1.2 \mathrm{mg} \mathrm{kg}^{-1}$ (DTPA extract) (Takkar and Mann, 1975). The plant available zinc in Indian soils, extracted with DTPA constitutes a very small portion $(<1 \%)$ of total zinc. The DTPA-extractable $\mathrm{Zn}$ in Indian soils ranges from 0.01 to $52.93 \mathrm{mg} \mathrm{kg}^{-1}$ soil. Analysis of 97,464 soils from all over India showed that $40 \%$ of the soil samples were potentially zinc-deficient. Zinc deficiency in soils of India is likely to increase from 49 to $63 \%$ by the year 2025 as most of the marginal soils brought under cultivation are showing zinc deficiency (Arunachalam et al., 2013). Dobermann and Fairhurst (2000) observed that zinc deficiency occurs mostly in neutral and calcareous soils. Crop species markedly differ in their ability to adapt to Zn deficient soils (Graham, 1984). Application of zinc fertilizer is essential in keeping sufficient amount of available $\mathrm{Zn}$ in soil solution, maintaining adequate $\mathrm{Zn}$ transport to the seeds during reproductive growth stage and increasing the yield.

Living in a tropical country like India we cannot avoid cereals and cereal based foods leading to micronutrient deficiency. So enriching and enhancing the diet with nutrient rich foods agronomically is the best solution today. Millets are the best alternative. Pearl millet [Pennisetum glaucum (L.)] is a dual purpose crop with food, feed and fodder value. Its grain is staple food of people living in arid regions of ancient India and also has a high feed value for livestock, poultry and fish. It also provides high quality green forage in seasons of fodder scarcity. In India, the average yield of pearl millet in the country as well as in the state (Tamil Nadu) is quite low as compared to its potential yield because it is grown in the marginal areas with poor management practices. So, there is considerable scope for increasing the productivity of pearl millet by adopting better agronomic practices in the high yielding hybrids/varieties. Productivity of any crop depends on many management factors: fertilizer being the major one. The application of $\mathrm{Zn}$ fertilizers for alleviating $\mathrm{Zn}$ deficiency in animals and humans is one of the most efficient and sustainable solution in the development and use of Zn-efficient plant genotypes that can more effectively function under low soil $\mathrm{Zn}$ conditions, which would reduce fertilizer inputs, less time consuming process and protect the environment as well. It has been well documented that certain plant species, as well as genotypes within certain species, exhibit a significant genetic-based variation in their tolerance to $\mathrm{Zn}$ deficiency. The ability of a genotype to grow and yield well in a $\mathrm{Zn}$ deficient soil is termed as " $\mathrm{Zn}$ efficiency" (Hacisalihoglu and Kochian, 2003). Genotypic differences for zinc use efficiency have been reported in several crops species (Cakmak et al., 2010). Keeping above points in view, the objective of the present study was to screen pearl millet genotypes in relation to $\mathrm{Zn}$ use efficiency in calcareous soil through fertilization strategy.

\section{Materials and Methods}

A greenhouse experiment was conducted in the Department of Soil Science and Agricultural Chemistry, Agricultural College and Research Institute, Coimbatore during $2016-17$, to evaluate $\mathrm{Zn}$-use efficiency of eighteen pearl millet (Pennisetum glauccum) genotypes. The soil used in the experiment was sandy clay loam in texture classified taxonomically as Vertic Ustropept. The details of the initial soil analysis are furnished in table 1 .

The treatments consisted of two $\mathrm{Zn}$ levels, i.e., without ( $0 \mathrm{mg} \mathrm{Zn} \mathrm{kg}^{-1}$ of soil) and with $\mathrm{Zn}$ application (10 $\mathrm{mg} \mathrm{Zn} \mathrm{kg}^{-1}$ of soil) and 18 pearl millet genotypes. The details of the pearl millet genotypes used in the study are given in table 2 . 
The experiment was conducted in a completely randomized design with factorial arrangement, and treatments were replicated thrice. The study was conducted in plastic pots each containing $7 \mathrm{~kg}$ of soil with three plants. All the pots received $\mathrm{N}, \mathrm{P}_{2} \mathrm{O}_{5}$ and $\mathrm{K}_{2} \mathrm{O}$ at the rate of 80:40:40 respectively $\mathrm{kg} \mathrm{ha}^{-1}$. The zinc was applied in the form of zinc sulphate. The study was carried out up to pre flowering stage as per the procedure followed for selecting zinc efficient genotypes. At the end of the experiment (pre flowering stage) dry matter yield of shoot was recorded. The plant material was dried in a hot air oven at about $70^{\circ} \mathrm{C}$. Zinc content of the plant was determined by triple acid extraction method (Lindsay and Norvell, 1978). Genotype classification based on nutrient use efficiency (Fageria and Baligar, 1997) otherwise can be termed as Efficient Genotype Index (EGI) was calculated with the dry matter yield and zinc concentration of each genotype given in table 4. Using the formula given below and thereafter classifying the genotypes using a scattered diagram.

Zinc Use Efficiency (each genotype $)=($ dry matter yield at high $\mathrm{Zn}$ application level/ $\mathrm{Zn}$ content at high $\mathrm{Zn}$ application level) - (dry matter yield without $\mathrm{Zn}$ application level / Zn content at without $\mathrm{Zn}$ application level)

The zinc efficient and inefficient pearl millet genotypes were identified based on the screening of cultivars by drawing a scattered diagram using ZUE of each genotype. A graph (Fig. 1) was drawn plotting dry matter yield of all the genotypes obtained for without zinc application in the $X$ axis and corresponding $\mathrm{Zn}$ use efficiency in $\mathrm{Y}$ axis. The perpendicular and parallel line to $X$ axis were drawn with average dry matter yield and zinc use efficiency to divide the scattered diagram and to classify the genotypes into four groups viz. efficient and responsive (ER), efficient and non-responsive (ENR), inefficient and responsive (IER) and inefficient and non-responsive (IENR). The ER genotypes have high yield as well as high zinc use efficiency, ENR genotypes have high yield and low efficiency, IER genotypes have low yield and high efficiency and IENR have low yield as well as low efficiency. The ER genotypes would be most suitable for cultivation under $\mathrm{Zn}$ stress conditions.

The data on various observations recorded during the course of investigation were analyzed statistically by adopting the procedure described by Gomez and Gomez (2010).

\section{Results and Discussion}

The results of the analysis of variance for the variables measured showed less effect of $\mathrm{Zn}$ treatment; however, genotypes had significant differences in relation to dry matter production and zinc concentration (Table 3 ).

\section{Dry Matter Production}

The expression of plant productivity in terms of the dry weight of material produced per unit area during a specified time period though had less significance of variation with the application of zinc fertilizers, significantly varies among the different genotypes studied. The maximum and minimum dry matter production (DMP) with zinc treatment was found to be $3330 \mathrm{~kg} \mathrm{ha}^{-1}$ and $1920 \mathrm{~kg} \mathrm{ha}^{-1}$ as against the treatments that received no zinc application which recorded between $3010 \mathrm{~kg}$ $\mathrm{ha}^{-1}$ and $1900 \mathrm{~kg} \mathrm{ha}^{-1}$ for various genotypes. This variation might be due to prolonged uptake of nutrients from soil and also due to differential ability of genotypes for absorbing and accumulating micronutrients (Anandan et al., 2011).

Among the genotypes, CO 9 had the highest DMP in both with zinc (3330 kg ha ${ }^{-1}$ ) and 
without zinc $\left(3010 \mathrm{~kg} \mathrm{ha}{ }^{-1}\right)$ treatment compared to other genotypes and this variation might be due to their differential utilization capacity of native soil $\mathrm{Zn}$ as well as applied zinc. Under zinc fertilization, genotypes viz., GHB $744\left(3156 \mathrm{~kg} \mathrm{ha}^{-1}\right)$ and Ankur $\left(3120 \mathrm{~kg} \mathrm{ha}^{-1}\right)$ were on par with each other recording the second highest DMP followed by CO $10\left(3010 \mathrm{~kg} \mathrm{ha}^{-1}\right)$, Namdari (3000 kg ha $\left.{ }^{-1}\right)$, GHB $719\left(3085 \mathrm{~kg} \mathrm{ha}^{-1}\right)$ and MYS 86M86 (3020 kg ha $\left.{ }^{-1}\right)$ which were on par with each other. Whereas CO $10(2800 \mathrm{~kg}$ $\left.\mathrm{ha}^{-1}\right)$ followed by MYS 86M16 (2760 kg ha $\left.{ }^{1}\right)$,MYS 86M86 (2728 $\left.\mathrm{kg} \mathrm{ha}^{-1}\right)$, Namdari (2700 kg ha ${ }^{-1}$ ), GHB 905 (2700 kg ha ${ }^{-1}$ ), MYS 86M84 (2700 kg ha' $\left.{ }^{-1}\right)$, GHB 744 (2680 $\left.\mathrm{kg} \mathrm{ha}^{-1}\right)$ and MYS 86M88 (2680 $\left.\mathrm{kg} \mathrm{ha}^{-1}\right)$ recorded comparable DMP in the control (0 $\mathrm{mg} \mathrm{kg} \mathrm{ha}{ }^{-1}$ zinc) which were on par with each other. Tolerance of certain genotypes under zinc stress conditions might be due to their higher rates of organic acid excretion in the rhizosphere facilitating increased native $\mathrm{Zn}$ availability in soil (Kabeya and Shankar, 2013). Efficient and responsive genotypes CO 9, Pioneer, GHB 744, MYS 86M84, MYS 86M86 and MYS 70428 were found to have 9.6, 15.5, 6.6, 9.7 and 12.8 percent increase in dry matter yield over control respectively.

\section{Zinc content in Plant}

Plant $\mathrm{Zn}$ concentration considered as a measure of efficient $\mathrm{Zn}$ acquisition and its transport to shoot. The different cultivars varied greatly in respect of zinc concentration before flowering stage. The mean zinc concentration varied from 22.65 to $70.24 \mathrm{mg}$ $\mathrm{kg}^{-1}$ in different genotypes during preflowering stage. Genotype CO 9 had the highest zinc concentration of 67.32 and 70.24 $\mathrm{mg} \mathrm{kg}{ }^{-1}$ while MYS 86M86 had the lowest zinc concentration of 22.65 and $24.63 \mathrm{mg} \mathrm{kg}^{-1}$ in both control and zinc applied at $10 \mathrm{mg} \mathrm{kg}^{-1}$ of soil. The different genotypes taken for study showed wide variation in total plant zinc concentration under no zinc treatment which may be due to the secretion of the phytosiderophores, a type of nonproteinogenic amino acids from the roots of efficient genotypes under zinc stress conditions and which are highly effective in complexing and mobilizing $\mathrm{Zn}$ from root apoplast to long distance transport of $\mathrm{Zn}$ within the plant (Cakmak et al., 1998). The lowest zinc concentration was recorded by MYS hybrids and highest by TNAU hybrids and these differences could be due to differential ability of the genotypes in extracting zinc from the soil solution and diffusion of zinc and its redistribution (Grotz and Guerinot (2006). It was noteworthy to observe that the genotypes CO 9(T1: 67.32; T2: 70.24) followed by CO 10 (T1: 60.65; T2: 64.23) recorded significantly higher zinc concentrations (in $\mathrm{mg} \mathrm{kg}^{-1}$ ) in both the treatments. Pioneer (57.63) and Namdari (57.12) were on par with each other followed by Ankur (53.98), MYS 86M88 (53.19) and Mahindra(52.32) which were also on par with each other in recording higher zinc concentrations in dry matter of the plant(in $\mathrm{mg} \mathrm{kg}^{-1}$ ) in the control.

Zhao (2011) contemplated that increased supply of zinc favoured increased $\mathrm{Zn}$ accumulation in the entire plant. Crops fertilized with $\mathrm{Zn}$ improved the nutritional environment of rhizosphere and consequently in plant system, which might have caused higher metabolic and photosynthesis activity in plant resulted in greater accumulation of zinc by crops and higher dry matter production (Kanwal et al., 2010). Among the genotypes, GHB 719 showed higher treatment variation of 19 per cent in zinc content and the lowest of 3.53 percent was observed for MYS 86M86 hybrid. The $\mathrm{Zn} \times$ genotype interaction was significant, indicating variation in zinc concentration among genotypes with the variation in $\mathrm{Zn}$ fertilization. 


\begin{tabular}{|c|c|c|c|}
\hline \multicolumn{4}{|c|}{ Table.1 Initial soil characteristics of experimental soil } \\
\hline Parameters & Result & Procedure & Reference \\
\hline Soil texture & Sandy clay loam & International pipette method & Piper (1966) \\
\hline Soil pH & 8.15 & \multirow[t]{2}{*}{ 1:2.5 soil water suspension } & \multirow[t]{2}{*}{ Jackson (1973) } \\
\hline Soil EC & $0.45 \mathrm{dSm}^{-1}$ & & \\
\hline Organic carbon & $7 \mathrm{~g} \mathrm{~kg}^{-1}$ & Chromic acid wet digestion & Walkley and Black (1934) \\
\hline Free $\mathrm{CaCO}_{3}$ & 17 per cent & Volumetric titration & Piper (1966) \\
\hline Available $\mathrm{N}$ & $280 \mathrm{~kg} \mathrm{ha}^{-1}$ & Alkaline permanganate method & Subbiah and Asija (1956) \\
\hline Available P & $19 \mathrm{~kg} \mathrm{ha}^{-1}$ & $0.5 \mathrm{M} \mathrm{NaHCO}_{3}(\mathrm{pH}-8.5)$ & Olsen et al., (1954) \\
\hline Available K & $416 \mathrm{~kg} \mathrm{ha}^{-1}$ & Neutral $\mathrm{N} \mathrm{NH}_{4} \mathrm{OAC}$ & Stanford and English (1949) \\
\hline DTPA- Zn & $0.750 \mathrm{mg} \mathrm{kg}^{-1}$ & \multirow{4}{*}{$\begin{array}{l}\text { DTPA extraction and AAS } \\
\text { method }\end{array}$} & \multirow[t]{4}{*}{ Lindsay and Norvell (1978) } \\
\hline DTPA- Fe & $0.465 \mathrm{mg} \mathrm{kg}^{-1}$ & & \\
\hline DTPA- $\mathrm{Cu}$ & $1.499 \mathrm{mg} \mathrm{kg}^{-1}$ & & \\
\hline DTPA- Mn & $17.05 \mathrm{mg} \mathrm{kg}^{-1}$ & & \\
\hline
\end{tabular}

\begin{tabular}{|l|l|l|l|}
\hline \multicolumn{4}{|c|}{ Table.2 Details of the genotypes used in the study } \\
\hline S.No & Name of Genotypes & Source (Location) & Type \\
\hline 1. & CO9 & TNAU & Hybrid \\
\hline 2. & CO 10 & TNAU & Hybrid \\
\hline 3. & ANKUR & Tamil Nadu (Private) & Hybrid \\
\hline 4. & MAHINDRA & Tamil Nadu (Private) & Hybrid \\
\hline 5. & NAMDARI & Tamil Nadu (Private) & Hybrid \\
\hline 6. & PIONEER & Tamil Nadu (Private) & Hybrid \\
\hline 7. & GHB 538 & Jamnagar, Gujarat & Hybrid \\
\hline 8. & GHB 558 & Jamnagar, Gujarat & Hybrid \\
\hline 9. & GHB 719 & Jamnagar, Gujarat & Hybrid \\
\hline 10 & GHB 732 & Jamnagar, Gujarat & Hybrid \\
\hline 11. & GHB 744 & Jamnagar, Gujarat & Hybrid \\
\hline 12. & GHB 905 & Jamnagar, Gujarat & Hybrid \\
\hline 13. & MYS 86M88 & University of Mysore & Hybrid \\
\hline 14. & MYS 86M16 & University of Mysore & Hybrid \\
\hline 15. & MYS 86M84 & University of Mysore & Hybrid \\
\hline 16. & MYS 86M86 & University of Mysore & Hybrid \\
\hline 17. & MYS 86M66 & University of Mysore & Hybrid \\
\hline 18. & MYS 70428 & University of Mysore & Hybrid \\
\hline
\end{tabular}


Table.3 Zinc content and dry matter production of eighteen pearl millet genotypes at the end of the experiment (pre flowering stage)

\begin{tabular}{|c|c|c|c|c|c|}
\hline \multicolumn{6}{|c|}{ (Mean of three replications) } \\
\hline \multicolumn{2}{|c|}{ Genotypes } & \multicolumn{2}{|c|}{ Zinc Concentration ( $\mathrm{mg} \mathrm{kg}^{-1}$ ) } & \multicolumn{2}{|c|}{ Dry Matter Production $\left(\mathrm{kg} \mathrm{ha}^{-1}\right)$} \\
\hline S.NO & Details & $\mathbf{T}_{1}$ & $\mathbf{T}_{2}$ & $\mathbf{T}_{1}$ & $\mathbf{T}_{2}$ \\
\hline 1. & CO 9 & 67.32 & 70.24 & 3010 & 3330 \\
\hline 2. & CO 10 & 60.65 & 64.23 & 2800 & 3010 \\
\hline 3. & ANKUR & 53.98 & 63.26 & 2658 & 3120 \\
\hline 4. & MAHINDRA & 52.32 & 57.21 & 1900 & 2102 \\
\hline 5. & NAMDARI & 57.12 & 62.45 & 2700 & 3000 \\
\hline 6. & PIONEER & 57.63 & 60.98 & 2450 & 2900 \\
\hline 7. & GHB 538 & 50.36 & 52.12 & 1920 & 1990 \\
\hline 8. & GHB 558 & 39.23 & 45.32 & 1967 & 2280 \\
\hline 9. & GHB 719 & 47.03 & 56.28 & 2520 & 3085 \\
\hline 10. & GHB 732 & 30.45 & 32.75 & 2600 & 2800 \\
\hline 11. & GHB 744 & 38.96 & 44.93 & 2680 & 3156 \\
\hline 12. & GHB 905 & 37.82 & 41.35 & 2700 & 2980 \\
\hline 13. & MYS 86M88 & 53.19 & 58.35 & 2680 & 2980 \\
\hline 14. & MYS 86M16 & 25.81 & 27.46 & 2760 & 2995 \\
\hline 15. & MYS 86M84 & 37.99 & 39.33 & 2700 & 2890 \\
\hline 16. & MYS 86M86 & 22.65 & 24.63 & 2728 & 3020 \\
\hline 17. & MYS 86M66 & 24.12 & 27.13 & 2423 & 2756 \\
\hline 18. & MYS 70428 & 25.31 & 28.31 & 2590 & 2970 \\
\hline \multicolumn{2}{|c|}{ Average } & 43.44 & 47.57 & 2544 & 2854 \\
\hline \multicolumn{2}{|c|}{$\mathbf{T}$} & ** & ** & $* *$ & $* *$ \\
\hline \multicolumn{2}{|l|}{$\mathbf{G}$} & $* *$ & $* *$ & $* *$ & $* *$ \\
\hline \multicolumn{2}{|l|}{$\mathbf{T} \times \mathbf{G}$} & $* *$ & $* *$ & $* *$ & $* *$ \\
\hline \multicolumn{2}{|l|}{$\mathrm{CV}$} & \multicolumn{2}{|c|}{$2.91 \%$} & \multicolumn{2}{|l|}{$2.38 \%$} \\
\hline \multicolumn{2}{|l|}{ SED } & \multicolumn{2}{|l|}{1.09} & \multicolumn{2}{|l|}{52.38} \\
\hline \multicolumn{2}{|c|}{ CD (0.01) } & \multicolumn{2}{|l|}{2.88} & \multicolumn{2}{|l|}{138.60} \\
\hline \multicolumn{2}{|c|}{ CD (0.05) } & \multicolumn{2}{|l|}{2.17} & \multicolumn{2}{|l|}{104.43} \\
\hline
\end{tabular}

*T1: $0 \mathrm{mg} \mathrm{Zn} \mathrm{kg}^{-1}$ soil and T2:10 $\mathrm{mg} \mathrm{Zn} \mathrm{kg}^{-1}$ soil (applied as $\mathrm{ZnSO}_{4}$ ) 


\begin{tabular}{|l|l|c|c|c|c|}
\hline \multicolumn{5}{|c|}{ Table.4 Classification of Genotypes based on dry matter yield } \\
\hline S.No & Genotypes & DMP @ control & ZUE & Efficiency & Responsiveness \\
\hline G1 & CO 9 & 3010 & 2.70 & Efficient & Responsive \\
\hline G2 & CO 10 & 2800 & 0.70 & Non Efficient & Responsive \\
\hline G3 & ANKUR & 2658 & 0.08 & Non Efficient & Responsive \\
\hline G4 & MAHINDRA & 1900 & 0.43 & Non Efficient & Non Responsive \\
\hline G5 & NAMDARI & 2700 & 0.77 & Non Efficient & Responsive \\
\hline G6 & PIONEER & 2760 & 2.13 & Efficient & Responsive \\
\hline G7 & GHB 538 & 1920 & 0.06 & Non Efficient & Non Responsive \\
\hline G8 & GHB 558 & 1967 & 0.17 & Non Efficient & Non Responsive \\
\hline G9 & GHB 719 & 2520 & 1.23 & Non Efficient & Non Responsive \\
\hline G10 & GHB 732 & 2600 & 0.11 & Non Efficient & Responsive \\
\hline G11 & GHB 744 & 2680 & 1.45 & Efficient & Responsive \\
\hline G12 & GHB 905 & 2700 & 0.68 & Non Efficient & Responsive \\
\hline G13 & MYS1 86M88 & 2680 & 0.69 & Non Efficient & Responsive \\
\hline G14 & MYS2 86M16 & 2450 & 5.04 & Efficient & Non Responsive \\
\hline G15 & MYS3 86M84 & 2700 & 2.41 & Efficient & Responsive \\
\hline G16 & MYS4 86M86 & 2728 & 2.17 & Efficient & Responsive \\
\hline G17 & MYS5 86M66 & 2423 & 1.13 & Non Efficient & Non Responsive \\
\hline G18 & MYS 70428 & 2590 & 2.58 & Efficient & Responsive \\
\hline Average & $\mathbf{2 5 4 4}$ & $\mathbf{1 . 4}$ & & \\
\hline
\end{tabular}

Fig.1 A graph depicting classification of genotypes based on its efficiency

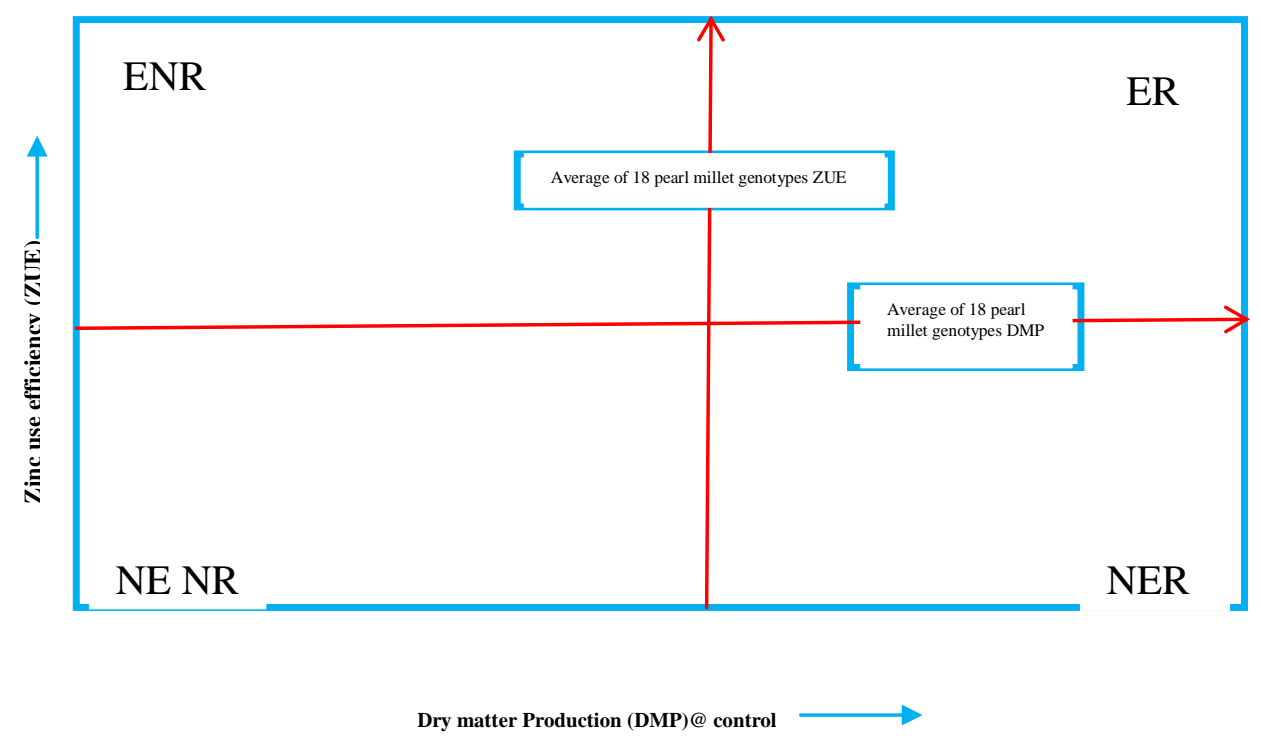


Fig.2 Screening of Zn efficient and inefficient pearl millet genotypes

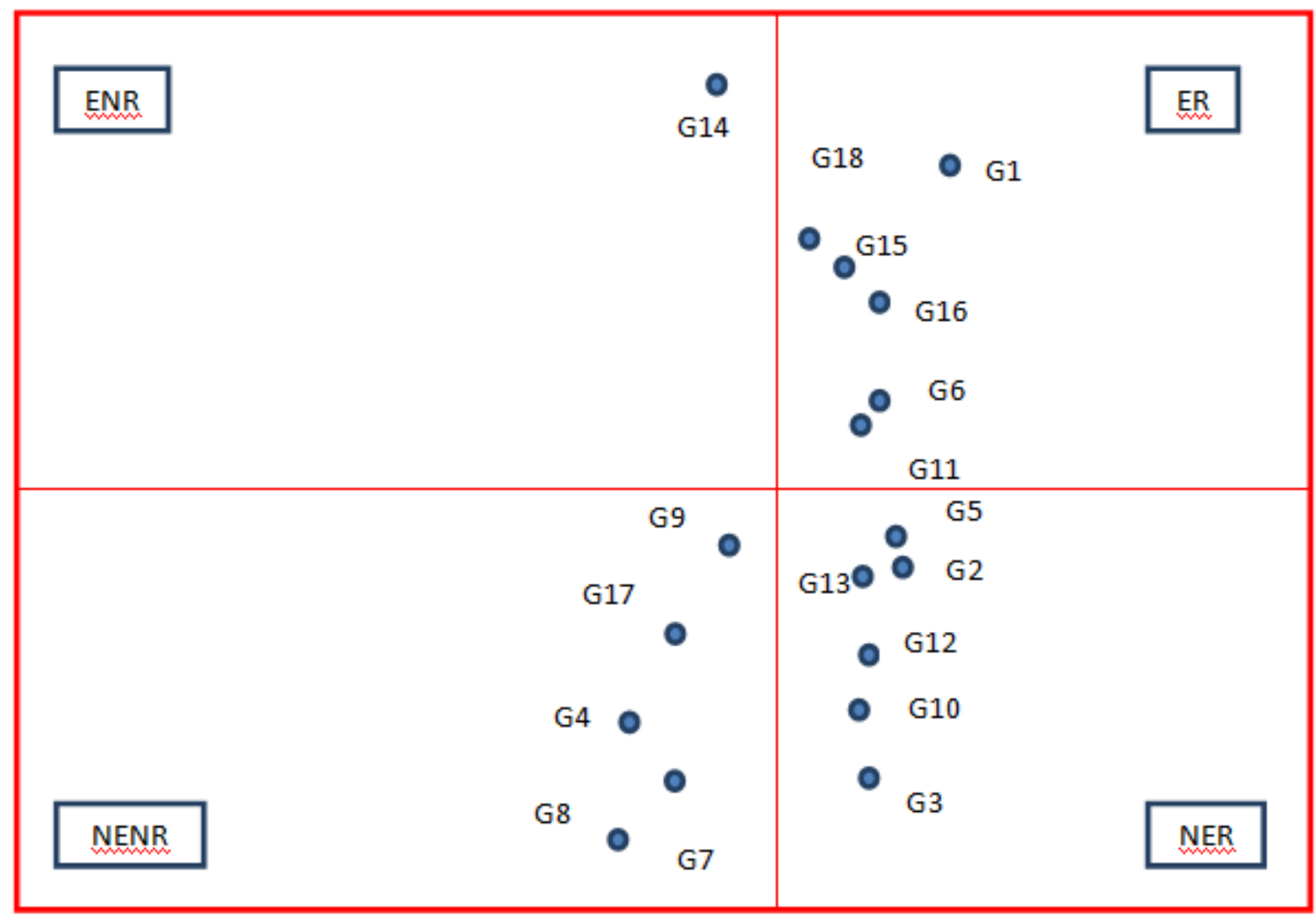

Classification of genotypes to zinc-use efficiency

Genotypes of pearl millet subjected to variation in zinc fertilization were classified into efficient, inefficient, responsive and nonresponsive groups using a scattered diagram. The zinc efficient genotypes were identified based on the screening of cultivars by drawing a scattered diagram using dry matter yield and zinc use efficiency as illustrated in Figure 1. According to this classification, genotypes falling under the category of Efficient Responsive (ER) would be most suitable for cultivation and improving the yield with higher zinc content under $\mathrm{Zn}$ stress and zinc fertilization in field conditions.

Regarding ZUE index, a value from 0.06 to 5.04 was recorded for different genotypes.
Among the genotypes, CO 9 registered a ZUE value of 2.69 followed by MYS 70428 (2.58), MYS 86M84 (2.41), MYS 86M86 (2.17), Pioneer (2.13), and GHB 744 (1.45) which were found to be efficient and responsive. Whereas MYS 86M16 was found to be efficient and not responsive (ENR) though with the high value of 5.04 as its ZUE and all the other genotypes were found to be inefficient (IER, IENR) (Table 4; Fig. 2). This variation might be attributed due to the fact that the zinc efficient genotypes produce higher dry matter production under deficient and adequate $\mathrm{Zn}$ supply, due to their ability to absorb higher zinc from the applied $\mathrm{Zn}$ fertilizers and to utilize for higher DMP as stated by Chaab et al., (2011). Though the Tamil Nadu private hybrids recorded higher concentration of zinc, they registered lower dry matter production than the other genotypes and thus did not fall 
under the category of efficient genotypes except Pioneer that recorded moderately higher zinc concentration and dry matter production. This difference in dry matter yield and varied zinc use efficiency has been used as indices to classify efficient, inefficient, responsive and non-responsive cultivars used in the study. Graham and Rengel (1993) suggested that more than one mechanism could be responsible for establishing $\mathrm{Zn}$ efficiency in a genotype and it is likely that different genotypes subjected to $\mathrm{Zn}$ deficiency under different environmental conditions will respond by, one or more, different efficiency mechanisms (Rengel and Wheal, 1997).

Zinc efficiency (ZE), mainly defined as the ability of a plant to grow and yield well under Zn deficiency. Hafeez et al., (2013) reported that efficient genotypes are those with high ability to absorb nutrients from soil and fertilizer, produce high biomass yield per unit of absorbed nutrient and store relatively less nutrients which is also evident from our study (Table 3).

The difference in nutrient absorption and utilization may be associated with root geometry, ability of plants to take up sufficient nutrients from lower or subsoil concentration, plants abilities to solubilize nutrients in the rhizosphere, better transport, distribution and utilization within plants and balance source sink relationships (Fageria and Baligar, 2003). Genotypes that are efficient in utilising $\mathrm{Zn}$, increased shoot weight more than genotypes responsive to $\mathrm{Zn}$ fertilisers. In contrast, $\mathrm{Zn}$ responsive genotypes increased zinc concentration more than Zn-utilisationefficient genotypes.

Thus screening with deficient sources could give a picture of the real efficiency of a genotype that would help in taking decisions on fertilizer application and provide required nutrition to the crop.
The identified efficient genotypes could be grown under $\mathrm{Zn}$ stress condition due to their differences in internal utilization or mobility of $\mathrm{Zn}$ that have been shown to be involved in expression of $\mathrm{Zn}$ efficiency. Among the genotypes studied, CO 9, Pioneer, GHB 744, MYS 86M84, MYS 86M86 and MYS 70428 were identified as most $\mathrm{Zn}$ efficient and responsive genotypes. Thus these efficient and responsive genotypes could be suggested to be grown under $\mathrm{Zn}$ stressed condition. Efficient and responsive genotypes $\mathrm{CO}$ 9, Pioneer, GHB 744, MYS 86M84, MYS 86M86 and MYS 70428 were found to have $4.2,5.5,3.4,8.1$ and 10.6 percent increase in zinc content over control respectively. Genotypes classified as responsive both as efficient and inefficient could be used under proper adaptation of zinc fertilization strategies. Zinc use efficient genotypes screened based on zinc use efficiency could be the best solution for improving zinc concentration and to avoid malnutrition in future. This approach of fertilization strategy in screening genotypes for nutrient use efficiency especially for micronutrients like zinc in a potentially nutrient deficient calcareous soil would avoid further wastage and fixation of nutrients and also maintain soil fertility to sustain crop productivity. This methodology of screening could be adopted for more time consuming genetic and breeding studies at the end to compare and evaluate the potential of different genotypes for nutrient removal from the soil as preface confirmation.

\section{Acknowledgement}

Our sincere thanks to the Department of Soil Science and Agricultural Chemistry, Tamil Nadu Agricultural University, Coimbatore for providing research and laboratory facilities and Maulana Azad National fellowship acting under University Grants Commission for providing funding facility. 


\section{References}

Anandan, A., G. Rajiv, R. Eswaran and M. Prakash.2011. Genotypic variation and relationships between quality traits and trace elements in traditional and improved rice (Oryza sativa 1.) genotypes.J. Food Sci., 76 (4): 122-130.

Arunachalam, P., P. Kannan, G. Prabukumar and M. Govindaraj. 2013. Zinc deficiency in Indian soils with special focus to enrich zinc in peanut. African J. Agrl. Res., 8 (50): 6681-6688.

Cakmak, I. and H. Marschner. 1998. Enhanced superoxide radical production in roots of zinc deficient plants. J. Exp.l Bot.,39: 1449- 1460.

Cakmak, I.2010. Biofortification of cereals with zinc and iron through fertilization strategy. In: Proceedings of the 19th World Congress of Soil Science, Soil Solutions for a Changing World, 1-6 August 2010, Brisbane, Australia. Published on DVD, 4-6.

Chaab, A., G. R. Savaghebi and B. Motesharezadeh. 2011. Differences in the zinc efficiency among and within maize cultivars in a calcareous soil. Asian J. Agric. Sci., 3 (1): 26-31.

Combs, Jr., G.F., R.M. Welch, J.M. Duxbury, N.T. Uphoff and M.C. Nesheim (eds). 1996. Food-based approaches to preventing micronutrient malnutrition: An International Research Agenda. Cornell University, Ithaca, N.Y.

Dobermann, A. and T. Fairhurst. 2000. Rice: Nutritional Disorders and Nutrient Management. Potash and Phosphate Institute of 12. References 145 Canada (PPI/PPIC) and International Rice Research Institute (IRRI), Singapore and Makati City, the Philippines.

Fageria, N.K. and V.C. Baligar. 1997. Upland rice genotypes evaluation for phosphorus use efficiency. J. Plant Nutrition., 20(4\&5): 499-509.
Fageria, N.K. and V.C. Baligar. 2003 Method for evaluation of lowland rice genotypes for nitrogen use efficiency. J. Plant Nutrition., 26: 1315-1333

Gomez, K. A. and A. A. Gomez. 2010. Statistical Procedures for Agricultural Research, $2^{\text {nd }}$ Edn. John Wiley and Sons, New York. p. 680.

Graham, R. D. 1984. Breeding for nutritional characteristics in cereals. Adv. Plant Nutr., 1: 57 - 102.

Graham, R. D. and Z. Rengel. 1993.Genotypic variation in Zn uptake and utilization by plants. In: Robson D, ed. Zinc in soils and plants. Dordrecht, The Netherlands: Kluwer Academic Publishers, 107-114.

Graham, R. D., M. Knez and R. M. Welch. 2012. How much nutritional iron deficiency in humans globally is due to an underlying zinc deficiency?Adv. Agron., 115: 1 - 40.

Graham, R.D., Ascher J.S. and S. C. Hynes. 1992. Selecting zinc efficient cereal genotypes for soils of low zinc status, Plant Soil, 146: 241 - 250.

Grotz, N. and M.L. Guerinot. 2006. Molecular aspects of $\mathrm{Cu}, \mathrm{Fe}$ and $\mathrm{Zn}$ homeostasis in plants. Biochem.Biophys.Acta., 17(63): 595608.

Hacisalihoglu, G and L.V. Kochain. 2003. Zinc efficiency is correlated with enhanced expression and activity of zinc-requiring enzymes in wheat. Plant physiology., 131(2): 595-602.

Hafeez, B., Y. M. Khanif, A. W. Samsuri, O. Radziah, W. Zakaria and M. Saleem. 2013. Direct and Residual Effect of Zinc on Zinc Efficient and Inefficient Rice Genotypes Grown under Less Zinc Content Submerged Acidic Condition. Comm. Soil Sci. Plant Analysis, 1-59.

Jackson, M. L. 1973. Soil Chemical Analysis. Prentice hall of India Pvt. Ltd., New Delhi. 
Kabeya, M. J and A. G. Shankar. 2013.Effect of different levels of zinc on growth and uptake ability in rice zinc contrast lines (Oryza Sativa L.). Asian J. Plant Sci. Res.,3(3): 112 -116.

Kanwal, S., Rahmatullah, A.M. Ranjha and R. Ahmad. 2010. Zinc Partitioning in Maize Grain after Soil Fertilization with Zinc Sulfate. Int. J. Agric. Biol.,12 (2) : 299 302.

Lindsay, W. L. and W. A. Norvell. 1978. Development of a DTPA soil test for zinc, iron, manganese and copper. Soil Sci. Am. J., 42 (1996): 421-428.

Olsen, S. R., C.V. Cole, F.F. Watanabe and A. L. Bean. 1954. Estimation of available phosphorus of soil extraction with sodium bicarbonate. U.S. Dept. Agric. Cir., $939: 1-19$

Piper, C.S. 1966.Soil and Plant Analysis.Hans Publishers, Bombay.pp : 15.

Rengel, $\mathrm{Z}$ and M. Wheal.1997. Basic parameters of $\mathrm{Zn}$ uptake by wheat are affected by herbicides chlorsulfuran. $J$. Exp. Bot., 48: 935 - 941.

Stanford, S., and L. English. 1949. Use of flame photometer in rapid soil tests of $\mathrm{K}$ and Ca. Agron. J., $41: 446$ - 447.

Subbiah, B. V. and C. C. Asija. 1956. A rapid procedure for estimation of available nitrogen in soils. Curr. Sci., 25: 259260.

Takkar, P. N. and M. S. Mann. 1975. Evaluation of analytical methods for estimating available $\mathrm{Zn}$ and responses of maize to applied $\mathrm{Zn}$ in major soil series of Ludhiana, Punjab. Agrochimica., 19: 420 - 429.

Walkley, A. and I.A. Black. 1934. An estimation of the digestion method for determining soil organic matter and proposed modification of the chromic acid filtration method. Soil Sci. J., 37: $27-38$

Zhao, A. 2011. Zinc Fertilization Methods on Zinc Absorption and Translocation in Wheat. J. Agrl. Sci., 3(1): 28-35.

\section{How to cite this article:}

Jemila, C. and Shanmugasundaram, R. 2017. Evaluating Pearl Millet (Hybrids) Genotypes for Zinc Use Efficiency through Fertilization Strategy Screening. Int.J.Curr.Microbiol.App.Sci. 6(11): 3033-3043. doi: https://doi.org/10.20546/ijcmas.2017.611.356 